\title{
ANALISIS IMPLEMENTASI KERJASAMA SISTER-PROVINCE ANTARA PROVINSI YOGYAKARTA DENGAN GYEONGSANGBUK-DO DALAM PENGEMBANGAN DESA
}

\author{
Sannya Pestari Dewi \\ Fakultas Ekonomi dan Sosial, Universitas AMIKOM Yogyakarta \\ email: sannya.pestari.dewi@amikom.ac.id
}

\begin{abstract}
Sister-city cooperation between Yogyakarta and Gyeongsangbuk-Do has existed for 10 years. It has shown that regional authorities are able to carry out cooperation across national borders continously, especially in developing rural areas. Sumbermulyo has unique characteristics, which has a diversity of religious adherents who become religious tourism. This village is also one of the largest rice producers in D.I Yogyakarta. However, the low level of education in this region also complements the complexity of the implementation of the collaboration between the two parties. This study aims to analyze implementation of sistercity cooperation between Yogyakarta and Gyeongsangbuk-Do in the development of Sumbermulyo village, Bantul. The implementation of sister-city cooperation is examined by model of implantation policy with four indicators namely communication, resources, disposition, and bureaucratic structure. From the four indicators it was found that the cooperation of D.I Yogyakarta and Gyeongsangbuk-Do in the development of Sumbermulyo village was not successful in its implementation, with only the disposition indicator being met from the program. This is also illustrated by the implementation of program only in the second year of the agreed five years. The failure of this program made the evaluation for the government in the application of sister-province further collaboration.
\end{abstract}

Keyword: sister-province; implementation; policy; cooperation.

\begin{abstract}
ABSTRAK
Kerjasama sister-city antara Yogyakarta dan Gyeongsangbuk-Do yang telah terjalin selama 10 tahun telah menunjukkan bahwa otoritas daerah mampu melaksanakan kerjasama melintas batas negara secara berkesinambungan, terutama mengembangkan wilayah pedesaan. Desa Sumbermulyo sendiri merupakan desa dengan karakteristik cukup unik yaitu memiliki keanekaragaman penganut agama yang menjadi wisata agama. Desa ini juga menjadi salah satu produsen padi terbanyak di D.I Yogyakarta. Namun, rendahnya tingkat pendidikan di wilayah ini juga melengkapi kompleksitas pelaksanaan kerjasama kedua belah pihak. Penelitian ini bertujuan untuk menganalisis kerjasama sister-city antara Yogyakarta dengan Gyeongsangbuk-Do dalam pengembangan desa Sumbermulyo, Bantul. Implementasi kerjasama sister-city diteliti pelaksanaanya dengan empat indikator yaitu komunikasi, sumberdaya, disposisi, dan struktur birokrasi. Dari keempat indikator tersebut ditemukan bahwa kerjasama D.I Yogyakarta dan Gyeongsangbuk-Do dalam pengembangan desa Sumbermulyo tidak berhasil dalam implementasinya, dengan hanya terpenuhinya indikator disposisi dari program tersebut. Ini juga tergambarkan dengan terhentinya program hanya pada tahun kedua dari lima tahun yang disepakati. Kegagalan program ini menjadikan evaluasi bagi pemerintah dalam penerapan kerjasama sister-province selanjutnya.
\end{abstract}

Kata Kunci: sister-province; implementasi; kebijakan; kerjasama. 


\section{PENDAHULUAN}

Perkembangan studi hubungan internasional telah mengalami pergeseran pasca perang dingin. Saat ini terdapat perluasan aktor, isu, dan ruang lingkup kajian dalam rumpun ilmu hubungan internasional. Era globalisasi telah membuka peluang bagi aktor-aktor non negara untuk berpartisipasi dalam interaksi internasional lebih masif. Aktor dalam kerjasama melintas batas negara tidak lagi didominasi negara. Hal ini dipengaruhi oleh pemberian kewenangan sendiri bagi pemerintah daerah untuk melakukan kerjasama internasional. Saat ini, pemerintah daerah telah memiliki peran dan kewenangan dalam pencapaian kepentingan nasional daerahnya melalui kerjasama antar pemerintah daerah dengan sub-bagian negara lain. Fenomena ini menimbulkan bentuk baru kerjasama internasional yang mana melibatkan satuan terkecil negara yaitu kota, desa, ataupun provinsi atau dikenal dengan kerja sama sister-city.

Bentuk kerjasama sister city di Indonesia sendiri telah diatur sejak tahun 1993 dengan diterbitkannya kebijakan dari Departemen Dalam Negeri yaitu SE-Mendagri No 193/1652/PUOD yang membahas prosedur pembentukan kerjasama sister-city (Sinaga, 2010). Kemudian disahkan dalam UU No.32 Tahun 2004 meskipun keberlanjutan pelaksanaan teknisnya tetap mengacu pada kebijakan dari Departemen Dalam Negeri. Sejak diturunkannya aturan diatas maka setiap daerah di Indonesia mulai giat melakukan inisiasi kerjasama dengan wilayah lain yang melintas batas negara.

Provinsi D.I. Yogyakarta merupakan salah satu provinsi yang intensif membangun inisiasi kerjasama dengan pemerintah lain diluar batas negara Indonesia. Bahkan, Yogyakarta terus berusaha mempertahankan keberlangsungan program hubungan kerjasama luar negeri dengan berbagai wilayah diluar Indonesia, seperti kerjasama dengan Kyoto dimana hubungan kedua daerah ini telah terjalin sejak tahun 1985 sampai saat ini (Mukti, 2013). Selain dengan Kyoto, Yogykarta juga mengembangkan kerjasama dengan negara Asia Timur lainnya, yakni Korea Selatan. Sejak tahun 2008, Yogyakarta telah melakukan inisiasi kerjasama dengan salah satu provinsi di Korea Selatan yaitu provinsi Gyeongsangbuk-Do dibidang pengembangan desa (Humas Pemda DIY, 2019).

Implementasi dari program kerja sister-city antara Yogyakarta dan GyeongsangbukDo dalam pemberdayaan desa telah dilaksanakan sejak tahun 2009. Pada awalnya, kerjasama ini dilaksanakan di Desa Kampung, Kecamatan Ngawen, Gunung Kidul. Program kerjasama ini telah berhasil terlaksana di Desa Kampung dengan adanya pembangunan infrastruktur Gedung Saemaul dan peningkatan pada budidaya sapi. Hal ini menarik Gyeongsangbuk-Do untuk memperluas program kerjasamanya ke desa lainnya di Yogyakarta pada tahun 2015 (Indraswari, 2015). Desa Sumbermulyo adalah salah satu desa yang dipilih Gyeongsangbuk-Do untuk program pembangunan desa pada periode tersebut. Namun, kemajuan dari program kerjasama pembangunan desa Sumbermulyo ini masih minim untuk dievaluasi ataupun diketahui keberlanjutan programnya.

Desa Sumbermulyo merupakan desa dengan karakteristik cukup unik. Desa tersebut memiliki keanekaragaman penganut agama bahkan hal tersebut tergambar dari corak bangunan ibadah di wilayah tersebut dan jarak antar tempat peribadatan yang saling berdekatan. Wisata agama dan budaya di desa Sumbermulyo juga menjadi salah satu potensi besar bagi pengembangan desa. Berdasarkan data tahun 2017, penduduk desa Sumbermulyo terdiri dari empat penganut agama yang hidup berdampingan, yakni penganut agama Kristen, Islam, Katolik, dan Hindu (Humas Desa Sumbermulyo, 2019). Selain itu, masyarakat Sumbermulyo yang didominasi oleh buruh tani menjadikan desa ini sebagai salah satu desa penghasil komoditas tani di Yogyakarta. Namun, tingkat pendidikan masih rendah di desa ini dilihat dari data tahun 2015, desa Sumbermulyo memiliki jumlah pendudukan yang masih banyak berlatarbelakang SD, SMP, dan SMA dibandingkan 
perguruan tinggi (Prayogo \& Setiawati, 2017). Kondisi keberagaman agama di desa ini dan rendahnya tingakt pendidikan merupakan suatu hal yang kompleks dalam penerapan kerjasama sister-city antara Yogyakarta dan Gyeongsakbu-Do, karena akan ada pengaruh faktor sumber daya dari interaksi antar penduduk di desa tersebut. Periode kerjasama yang sudah memasuki 10 tahun dan kompleksitas kondisi masyarakat serta kebaharuan dari penerapan konsep sister-city ditingkatan terkecil desa dirasakan perlu untuk dikaji lebih dalam pada programnya, sehingga menimbulkan pertanyaan bagaimana efektivitas implementasi kerjasama sister-city antara Yogyakarta dan Gyeongsangbuk-Do dalam pengembangan desa Sumbermulyo, Bantul?

\section{TINJAUAN PUSTAKA}

Penelitian ini mengembangkan kerangka befikir dari konsep sister-city dan pendekatan implementasi kebijakan publik dalam menganalisis kerjasama antara D.I. Yogyakarta dan Provinsi Gyeongsangbuk-Do pada pengembangan desa di periode 20152020.

\section{Konsep Kerjasama Sister-City}

Kerjasama Sister-City atau dalam bahasa Indonesia disebut dengan kota kembar adalah bentuk kerjasama internasional dengan aktor yang berperan bukan negara melainkan satuan kecil dari negara seperti provinsi, kabupaten, atau kota. Konsep kerjasama kota kembar merupakan kerjasama yang dilakukan dua kota berbeda melintas batas negara mereka dengan tujuan membangun hubungan budaya dan kontak sosial antar penduduk (Primawanti, Dermawan, \& Ardiyanti, 2019). Menurut Sinaga (2010), penggambaran konsep kota kembar ini seperti sebuah bentuk "sahabat pena" antara kota di negara yang berbeda.

Tujuan dari kerjasama sister-city sendiri lebih banyak kepada pengembangan ekonomi ataupun peningkatan instrumen pembangunan dalam tata kelola kota serta cara untuk berbagi kebutuhan akan pengetahuan, sumber daya, teknologi, dan pakar diantara dua kota (Sitinjak, Sagala, \& Rianawati, 2014). Kehadiran kerjasama antar kota dari dua wilayah negara berbeda akan membawa suatu pembaharuan antar kedua wilayah dan membantu adanya percepatan pembangunan ekonomi di wilayah tersebut.

Konsep kerjasama kota kembar ini dilaksanakan dengan aturan formal dan mengikat antara dua pemerintah lokal dari wilayah negara berbeda demi menciptakan kemajuan bagi kedua belah pihak. Saat ini program sister-city sudah menaikkan solidaritas dan perdamaian dunia melalui pertukaran kebudayaan antar kota yang melintas batas negara (Sinaga, 2010). Oleh karenanya, prospek ke depan dari jalinan kerjasama dalam bentuk sister-city dapat menjadi alternatif bagi pembangunan negaranegara berkembang dan secara berkala karena pertukaran ilmu pengetahuan, teknologi dan para ahli antara dua kota yang melakukan kerjasama.

Dari uraian diatas bisa diartikan secara sederhana bahwa kerjasama sister-city merupakan hubungan mitra antara pemerintah lokal dari dua negara berbeda sebagai upaya peningkatan program pembangunan berkelanjutan Oleh karenanya, proses implementasi dari kerjasama sister-city tersebut harus dievaluasi setiap waktu untuk memaksimalkan tujuan dari pembangunan daerah yang ingin dicapai melalui kerjasama tersebut. Menurut Kelowna (dalam Nuralam, 2018) terdapat beberapa prinsip yang menjadikan tolak ukur untuk membentuk kerjasama sister-city yaitu 1) kesamaan bersama, 2) potensi pertukaran, 3) hubungan keterkaitan satu dan lainnya, 4) masyarakat menjadi fokus programnya, 5) memberikan manfaat strategis, 6) Tidak melakukan kerjasama sister-city pada bidang yang sama dengan kota lainnya, 7) Stabilitas Politik. Ketujuh acuan ini digunakan untuk melihat kelayakan dari kerjasama 
sister-city, sehingga kerjasama tersebut dapat diukur pada proses implementasinya. Kerjasama tidak hanya dilakukan atas dasar ketertarikan atau hubungan diplomatik yang telah terjalin antar kedua wilayah, namun harus memperhatikan ketujuh hal tersebut pada program-program kerjasamanya.

\section{Indikator Efektivitas Kerjasama Sister-City}

Kerjasama sister-city pada pelaksanaannya akan menjelma menjadi sebuah kebijakan daerah yang harus dilaksanakan sesuai dengan target tahun pelaksanaannya serta mengikat publik. Manfaat dari sebuah implementasi kebijakan adalah menciptakan interaksi yang memungkinkan tujuan ataupun target dari kebijakan publik menghasilkan sebuah outcome (Sirajuddin, 2014).

Implementasi dari kebijakan publik merupakan suatu hal dinamis yang harus dievaluasi setiap tahun sehingga kebijakan terlaksana sesuai target dan memberikan kemajuan bagi publik. Oleh sebab itu, Edward (dalam Windiani, 2014) menjelaskan bahwa terdapat empat indikator yang bisa dipakai untuk mengukur pencapaian sebuah kebijakan, yaitu:

a. Komunikasi: penyampaian perintah dan informasi terkait kebijakan dari pembuat kebijakan sampai ke personelnya harus diformulasikan dengan jelas, akurat, dan konsistern, serta para personel harus mengetahui langkah apa saja yang harus dilakukannya unutk menyampaikan informasi tersebut dengan benar.

b. Sumber Daya: Tanpa adanya sumber daya manusia, material dan metode, maka pencapaian dari kebijakan suatu daerag belum dapat meningkat secara signifikan, meskipun komunikasi telah berjalan dengan baik, namun akan sia-sia tanpa sumber daya yang tepat dan cepat.

c. Disposisi: Apabila sikap dari implementator kebijakan tidak efektif dan tidak memiliki kapasitas untuk menerapakan kebijakan seperti komitmen, kejujuran, komunikatif, cerdik dan demokratis, maka pencapaian kebijakan tidak akan berjalan maksimal.

d. Struktur Birokrasi: Untuk mencapai implementasi kebijakan yang maksimal dibutuhkan peta organisasi yang menggambarkan hirarki sehingga mudah melakukan kordinasi dan pembagian tugas dalam sistem serta diperlukannya sebuah standar operasional agar aturan dalam birokrasi lebih sistematis dan memiliki landasan.

Penelitian sebelumnya dengan melihat efektifitas melalui implementasi kebijakan pada kerjasama sister-city telah dilakukan oleh Windiani pada kasus kerjasama Provinsi Jawa Tengah dengan negara bagian Quensland di bidang pertanian dengan hasil penelitian yang menyatakan bahwa implementasi kerjasama tidak berjalan efektif meskipun dari luar terlihat beberapa indikator berjalan dengan baik, namun beberapa indikator lainnya tidak dapat dipenuhi, seperti komunikasi, sumber daya keuangan, dan struktur birokrasi tidak dapat terpenuhi, serta ditemukan adanya kelemahan kewenangan dalam institusi dan peraturan pemerintah dalam pelaksanaan program kerjasama (Windiani, 2014). Indikator dari implementasi kebijakan dijadikan sebagai acuan untuk menganalisa sampai pada tingkatan mana kerjasama antara Gyeongsangbuk-Do dan Pemerintah D.I Yogyakarta dalam pengembangan desa Sumbermulyo.

\section{METODE}

Penelitian ini menggunakan metode kualitatif. Pendekatan kualitatif merupakan cara meneliti intuitif dan sistematis yang akan membuat pengetahuan secara efisien dan koheren. Pada penelitian kualitatif sendiri terdapat beberapa metode seperti wawancara untuk observasi, analisis wacana, dan historis, serta penelitian multi-metode. Penelitian dengan 
metode kualitatif memandang fenomena dan aktor dalam aturan alamiah peneliti, agar dapat mengartikan proses dan fenomena berdasarkan makna dan pertisipasi aktor dalam istilah dari para peneliti itu sendiri (Bakry, 2015). Sedangkan proses yang dipakai pada penelitian ini adalah proses deduktif dengan adanya konsep sister-city dan implementasi kebijakan publik yang dilihat pola interaksinya dalam sebuah studi kasus melalui kasus tunggal yakni di desa Sumbermulyo, Bantul. Pada penelitian ini, teknik pengumpulan data yang digunakan adalah teknik pengumpulan data dengan berbagai sumber, seperti dokumen, data arsip dan wawancara. Penelitian ini menggunakan analisis dengan data kualitatif sehingga terdapat tiga jenis teknik analisis data yang dipakai. Ketiga teknik analisis data tersebut ialah analytic induction, grounded theory, dan secondary analysis. Penelitian ini akan memakai analytic induction sebagai teknik dalam menganalisis data kualitatif yang didapatkan. Wawancara dilakukan dengan pelaksana kegiatan kerjasama di tingkat desa Sumbermulya beserta dokumen-dokumen kegiatan yang terkait, seperti laporan kegiatan program, kesepakatan kerjasama, RPJMDesa, dan lainnya.

\section{HASIL DAN PEMBAHASAN}

Kerjasama sister-city yang dilakukan pemerintah D.I. Yogyakarta dengan Provinsi Gyeongsangbuk-Do merupakan satu dari 7 kerjasama sister-city. Pada pelaksanaannya, kerjasama ini telah melaksanakan berbagai kegiatan di tingkat provinsi, mulai dari pembangunan infrastruktur, pengembangan sumberdaya manusia, pertukaran budaya, sampai pada pengembangan desa. Pada tahun 2015, kerjasama sister-city ini mulai berfokus pada pengembangan desa. Hal ini dilatarbelakangi oleh perubahan dari Kementerian Transmigrasi menjadi Kementerian Desa dan Pembangunan Daerah Tertinggal (KPDT) di masa awal pemerintahan Presiden Jokowi (Indraswari, 2015). Perubahan kementerian tersebut sebagai upaya pemerintahan Jokowi untuk mempercepat pembangunan desa di Indonesia. Program pembangunan desa dari pemerintah pusat ini kemudian membuka peluang untuk membentuk kerjasama dengan negara lain, sehingga memberikan desa kesempatan tersendiri untuk bekerjasama dengan daerah lain diluar batas geografis negaranya.

Korea Selatan menjadi salah satu negara yang tertarik untuk ikut bekerjasama dalam pembangunan desa-desa di Indonesia. Ketertarikan Korea Selatan tersebut diwujudkan dengan mulai membuka jalan bagi provinsi-provinsi di negaranya untuk menjalin kerjasama sister-city dengan desa-desa di Indonesia. Provinsi Gyeongsangbuk-Do menjadi salah satu mitra kerjasama D.I. Yogyakarta dalam mewujudkan program pengembangan desa yang menjadi salah satu program besar pemerintahan Jokowi. Keberhasilan Korea Selatan membangun pedesaannya melalui konsep Saemul Undong menjadi latarbelakang kemitraan antara Indonesia dan Korea Selatan.Karakteristik dari konsep Saeumul Undong yang memiliki kemiripan dengan sistem gotong royong yang ada di Indonesia dilihat memiliki potensi besar untuk dikembangkan sebagai desa kembar. Selain itu, pengalaman sejarah sebagai negara yang pernah dijajah juga melatarbelakangi kesamaan karakter kedua negara untuk bisa membentuk kemitraan pada program pembangunan baik di pusat maupun daerah, dimana penelittian ini lebih berfokus pada konteks pembangunan desa.

\section{Gambaran Umum Kerjasama sister province Gyeongsangbuk-Do dengan D.I. Yogyakarta}

Kerjasama antara pemerintah D.I Yogyakarta dengan Gyeongsangbuk-Do dimulai sejak tahun 2001 dengan adanya utusan dari Gyeongsangbuk-Do telah berkunjung dan meninjau beberapa potensi kerjasama seperti proyek pembangunan Pantai Selatan pada saat itu. Pada tahun 2003, penandatanganan Letter of Intentent (LoI) antara D.I Yogyakarta dan Gyeongsangbuk-Do dilakukan dengan hasil kerjasama berupa 
penunjukan satu orang warga Gyeongsangbuk-Do sebagai Honor Advisor of Yogyakarta for International Cooperation, kunjungan gubernur Gyeongsangbuk-Do pada tahun 2004, dan pemberian pinjaman kepada pemerintah D.I Yogyakarta dari pemerintah Gyeongsangbuk-Do untuk pembangungan perpanjangan landasan Bandara Adi Sucipto. Setelah berselang satu tahun diadakan tindak lanjut dari penandatanganan LoI sebelumnya yakni peresmian kerjasama melalui Memorandum of Understanding (MoU) antara kedua belah pihak. Namun, pada prosesnya penandatanganin mengalami kendala terkait jenis penamaan surat kerjasama yang mana pihak Gyoengasangbuk-Do meminta untuk memakai "agreement" sebagai bentuk surat kerjasama, tetapi di pihak D.I Yogyakarta lebih mengacu pada MoU sebagai landasan resminya. Menurut Gyeongsangbuk-Do bentuk kerjasama menggunakan MoU merupakan sebuah kesepakatan yang tidak mengikat secara hukum. Permasalahan ini kemudian dapat diselesaikan dengan adanya loby-loby pada tingkat yang lebih tinggi untuk menyamakan persepsi tentang keterikatan hukum kerjasama yang dilakukan (Mukti, 2013).

Pelaksanaaan kerjasama tersebut di tingkat provinsi secara efektif mulai dikerjakan sejak tahun 2007. Hal ini dikarenakan Provinsi D.I Yogyakarta mengalami bencana gempa di tahun 2006, tetapi pada tahun tersebut tetap diadakan satu pelaksanaan program kerjasama yaitu studi banding bagi PNS Pemda DIY dalam program Korean Language Training Program for Sister City Public Officials. Di tahun 2007 pengenalan tentang gerakan Saemul yang ingin diterapkan pada pedesaan yang ada di Yogyakarta dimulai melalui kunjungan delegasi dari Pemda D.I. Yogyakarta ke Gyreongsangbuk-Do untuk mengikuti workshop Saemul Movemonet.

Inisiasi program pengembangan desa antara D.I Yogyakarta dan GyeongsangbukDo mulai dikerjakan pertama kali pada kurun waktu 2008-2012 di beberapa desa sebagai pilot projectnya yaitu desa Kampung Ngawen, Pacarejo, Banjarjoyo, Karangtalun, dan Salamrejo. Hasil dari kerjasama yang dilakukan pada keempat desa tersebut berupa bangunan fisik (Gedung Saemaeul) di desa Kampung Ngawen, dan penerapan prinsipprinsip bekerja keras, disiplin, dan hidup, bergotong kepada masyarakat desa atau disebut dengan program Saemaeul Undong (Mukti, 2013). Pemilihan D.I Yogyakarta sebagai mitra kerjasama dalam pembangunan desa ini dikarenakan masyarakat pedesaan di Yogyakarta masih memiliki budaya gotong-royong yang kuat sehingga memiliki potensi untuk berkembang seperti pedesaan di Gyeongasngbuk-Do. Program tersebut berhasil membuat satu desa menghasilkan satu produk unggulannya, seperti di desa Kampung Ngawen dimana terdapat program penggemukan 15 sapi dimana warga desa ini mayoritas merupakan peternak sapi dan desa Triharjo sebagai desa penghasil gula semut. Keberhasilan program Saemaul Undong di beberapa desa tersebut kemudian menjadikan program ini diperluas ke beberapa desa lainnya untuk periode 2015-2020.

Pada periode kedua tersebut, pelaksanaan program pengembangan desa mengikutsertakan dua lembaga swadaya masyarakat untuk menjadi fasiiltator antara desa dan pihak Gyeongsangbuk-Do yaitu Saemaeul Globalization Foundation dan Yayasan Penabulu. Desa Sumbermulyo merupakan salah satu desa yang terpilih menjadi pilot project pada periode kedua. Pemilihan desa Sumbermulyo juga dilihat dari potensi desa dan daya juang swadaya masyarakat dalam mengembangkan komoditas unggulan dari desa tersebut.

\section{Pelaksanaan Kerjasama Sister-Province Pengembangan Desa Sumbermulyo}

Berdasarkan karakteristiknya, Sumbermulyo dilihat memiliki potensi dalam pengembangan produk unggulan. Hasil panen desa ini bisa mencapai 9 ton per hektar dalam satu kali panen. Oleh karena itu, desa ini menjadi salah satu pemasok kebutuhan padi di provinsi D.I Yogyakarta, terutama untuk Kabupaten Bantul. Gyeongsangbuk-do 
juga merupakan salah satu pusat pertanian di Korea Selatan. Ini bisa digambarkan dari 18\% penduduk mereka bergerak di bidang pertanian. Padi juga menjadi salah satu produk unggulan dari provinsi ini. Oleh sebab itu, Gyeongsangbuk-Do menduduki posisi keempat produsen padi di Korea Selatan. (Gyeongsangbuk-Do Website, 2018). Keunggulan dalam bidang pertanian padi tersebut adalah kemiripan kedua wilayah yang menjadi proyeksi untuk program pengembangan desa, khususnya di bidang pertanian. Selain itu, Gyeongsangbuk-Do ialah provinsi yang memiliki banyak kesamaan dengan provinsi D.I Yogyakarta. Kedua provinsi ini adalah provinsi yang kaya akan budaya dan peninggalan sejarah, salah satu contohnya bangunan kerajaan yang menjadi daya tarik kedua provinsi ini. Apabila D.I Yogyakarta memiliki Kraton, Gyeongsangbuk-Do juga memiliki Donggung Palace sebagai peninggalan masa kerajaan Korea Selatan (Occeñola, 2017).

Karakteristik yang tergambar diatas telah menunjukkan 7 tolak ukur seperti yang disebutkan Kelowna sebelumnya, sehingga program pengembangan desa di Sumbermulyo diperkirakan akan memiliki keberhasilan yang sama dengan program Saemul Undong sebelumnya di desa Kampung Ngawen dan Triharjo. Optimisme ini membuat kedua belah pihak menyetujui untuk melaksanaan program pengembangan desa dalam kurun waktu 5 tahun dimulai dari 30 September 2015. Pengembangan desa Sumbermulyo ini diresmikan dengan penandatanganan Memorandum of Understanding (MoU) sebagai landasan tertulis kerjasama sister-city yang diadakan di Sumbermulyo dengan Gyeongsangbuk-Do. Pada MoU yang tertulis tertera kesepakatan antara Saemaeul Globalization Foundation (SGF) selaku pendamping dari pemerintah Gyeongsangbuk-Do dan Yayasan Penabulu sebagai fasilitator dalam kegiatan pengembangan desa yang dilakukan.

Pada perjanjian kerjasama yang tertulis di MoU dikatakan bahwa ruang lingkup kerjasama yang dilakukan berupa peningkatan kapasitas dan penguatan nilai-nilai demokrasi dalam tata kelola pemerintahan desa yang baik. Interpretasi kegiatan dari perjanjian kerjasama ini berupa peningkatan pertanian produk unggul yakni padi dengan cara berganti alih menjadi padi semi organik seperti yang dikembangkan di Gyeongsangbuk-Do. Selain program pengembangan produk unggul, juga dilaksanakan program pemberdayaan perempuan dengan memberikan pelatihan kepada ibu-ibu kelompok wanita tani untuk memanfaatkan lahan pekarangannya dengan menanam tanaman obat keluarga, kemudian mereka diberikan bantuan berupa pupuk kandang dan media untuk menanamnya. Tidak hanya itu, setiap dusun di desa Sumbermulyo diberikan pelatihan pengelolaan bank sampah dan pemberian bantuan berupa alat timbang dan media untuk pengelolaan sampahnya di setiap dusun. Kelompok wanita tani disetiap dusun juga dibekali pengetahuan pengolahan produk yang dapat dijual melalui BUMDes seperti olahan pisang dan jagung. Pihak Korea Selatan juga memberikan bantuan lantai jemur bagi pertanian desa senilai 75 juta sebagai upaya untuk meningkatkan hasil panen padi di desa Sumbermulyo (Nursanti, Wawancara, 2019).

Namun, pada perjalanannya program pengembangan desa ini berhenti di tengah jalan dari masa yang disepakati pada MoU. Di akhir tahun 2017, program pengembangan desa tidak berjalan lagi dan diakhiri dengan peresmian gedung balai pelatihan dan pengembangan Saemaeul yang merupakan gedung bantuan dari Korea Selatan. Pembangunan gedung serbaguna tersebut diberikan bantuan senilai 1,5 $\mathrm{M}$ dari pemerintah Korea Selatan kepada panitia tersendiri pembangunan gedung yang diluar dari perangkat desa. Sehingga, laporan Pada masa dimulainya program sampai berakhir di tahun 2017, pelatihan peningkatan produk unggul bagi para petani yang menjadi 
program utama dari project ini hanya terlaksana 4kali. Saat pelaksanaan program terdapat pendampingan dari pihak Korea Selatan berjumlah tiga orang yang tinggal di perumahan warga dan berkantor di ruang serbaguna desa Sumbermulyo selama dua tahun pelaksanaan program. Penarikan relawan Korea Selatan dari desa Sumbermulyo diikuti dengan berakhirnya segala program pengembangan desa yang sudah disepakati. Pemutusan program kerjasama ini dilakukan oleh pihak Korea Selatan secara sepihak dengan alasan kehabisan dana operasional kegiatan, tetapi dua desa lainnya yaitu Ponjong dan Bleberan masih mendapatkan pendampingan berkelanjutan dari Korea Selatan. Oleh sebab itu, program pengembangan desa ini perlu dianalisis pelaksanaan kegiatannya sampai menyebabkan pemutusan perjanjian secara sepihak dari mitra kerjasama.

Program pengembangan desa dalam kerangka sister-province D.I Yogyakarta dan Gyeongsangbuk-Do dapat ditinjau melalui empat indikator implementasi kebijakan public, yakni: komunikasi, sumberdaya, disposis, dan struktur birokrasi.

\section{a. Komunikasi}

Pada variabel ini, pencapaian dari sebuah kebijakan bisa dilihat dari komunikasi yang berlangsung mulai dari perencanaan, pelaksanaan, sampai pada akhir program. Indikator yang dapat digunakan pada variabel ini adalah transmisi, kejelasan program, dan konsistensi. Transmisi yang dimaksudkan adalah proses penyampaian program kepada pihak-pihak yang terkait. Ini lebih kepada sosialisasi program mulai dari pemetaan kebutuhan desa sampai pada pelaksanaan program yang sesuai dengan kondisi desa. Apabila dikaji pada program pengembangan desa di Sumbermulyo, maka transmisi dari program ini harus melibatkan pemerintah D.I Yogyakarta (DIY), Pemda Kabupaten Bantul, BAPPEDA DIY, BAPPEDA BANTUL, Dinas Perizinan dan Penanaman Modal DIY, Kecamatan Bambanglipuro, Perangkat Desa Sumbermulyo, Kelompok Tani Sumbermulyo, Kelompok Wanita Tani Sumbermulyo, dan Perwakilan setiap dusun di desa Sumbermulyo. Pihak-pihak tersebut harus mengetahui apa yang akan dilaksanakan dan menjadi tujuan dari program secara jelas. Kemudian intruksi mengenai program yang berjalan tidak konsisten disampaikan kepada pihak tersebut. Oleh karenanya, indikator kejelasan dan konsistensi dapat terpenuhi.

Meninjau program pengembangan desa di Sumbermulyo ini terlihat bahwa program sendiri tidak disosialisasikan terlebih dahulu kepada kelompok sasaran yaitu kelompok tani, kelompok wanita tani, dan masyarakat desa Sumbermulyo. Ini diketahui bahwa tidak ada sosialisasi tersendiri terkait pemetaan masalah sebelum program dimulai dari pihak pemerintah D.I Yogyakarta maupun Korea Selatan sebagai mitra kerjasama. Pemerintah desa langsung diajak untuk menandatangani kesepakatan kerjasama dengan pihak Korea Selatan pada 30 September 2015 tanpa melibatkan pihak Pemda Bantul ataupun Pemerintah D.I Yogyakarta sebagai alur penyampaian program. Masyarakat desa Sumbermulyo juga langsung dihadapkan dengan materi program berupa penanaman padi semi organik, sehingga pada pelaksanaannya masyarakat menjalani kebingungan dan minim pengetahuan dasar mengenai padi organik ini. Ini juga harusnya menjadi pertimbangan bahwa masyarakat tani di Sumbermulyo mayoritas berpendidikan rendah (Prayogo \& Setiawati, 2017), maka akan sulit bagi mereka untuk menerima wawasan baru tanpa mempelajari dasarnya terlebih dahulu. Selain itu, pada empat kali pelaksanaan pelatihan pihak dari Pemerintah D.I Yogyakarta, Pemda Kabupaten Bantul, ataupun Dinas Perizinan dan Penanamaan Modal, bahkan pemerintah kecamatan Bambanglipuro tidak dilibatkan ataupun mengetahui pelaksanaan kegiatan dan 
perkembangannya. Semua kegiatan dibawah kewenangan mitra kerjasama yakni pihak Korea Selatan dan pihak desa hanya diminta untuk menyiapkan kelompok sasaran dan tempat (Nursanti, Wawancara, 2019). Sampai pada akhir program, hanya pemerintah D.I Yogyakarta diwakilkan oleh GKR Hemas yang hadir meresmikan gedung serbaguna bantuan Korea Selatan tersebut tanpa mengetahui perkembangan program di lapangan. Kegagalan variabel komunikasi ini juga semakin tercermin pada indikator kejelasan dan konsistensi program dimana pada perjanjian tertulis bahwa program akan dilaksanakan dalam kurun waktu 5 tahun, namun kenyataannya di lapangan program hanya berlangsung selama dua tahun.

b. Sumberdaya

Pencapaian tujuan dari kebijakan harus diikuti dengan sumberdaya yang memadai, mulai dari sumberdaya manusia dan keuangan dari program tersebut. Variabel ini dapat tergambar dari indikator kapabilatas pelaksanaan program, yaitu pendanaan program, kualitas dan kuantitas sumberdaya manusia memiliki kesesuaian dengan kelompok sasaran dan program yang dilaksanakan, serta fasilitas yang diperlukan memadai dengan program yang dikerjakan.

Pada program kerjasama sister-province antara Gyeongsangbuk-Do dan D.I Yogyakarta diketahui bahwa adanya kekurangan dana untuk pelaksanaan program hingga lima tahun sesuai MoU. Ini menjadi alasan program ini berhenti di tahun kedua pelaksanaannya. Untuk kualitas dan kuantitas sumberdaya manusia juga terdapat kekurangan yang mana pendamping dari pihak Korea Selatan hanya berjumlah tiga orang sedangkan kelompok target yang akan dibina sejumlah 17 kelompok tani atau berkisar $2000 \mathrm{KK}$. Kualitas pendidikan sendiri bisa dikaji dengan melihat keahlian para pendamping pada program yang dilaksanakan dimana para pendamping tersebut hanya memberikan instruksi target yang harus dicapai kelompok sasaran, tetapi tetap menghadirkan narasumber dari dinas pertanian D.I Yogyakarta sebagai pemateri pelatihan, sedangkan pemahaman tentang produk padi semi organik seperti di Gyeongsangbuk-Do akan lebih jelas bila dijelaskan oleh perwakilan dari Gyeongsangbuk-Do. Kemampuan berbahasa Indonesia yang minim dari relawan Korea Selatan tersebut menunjukkan bahwa kualitas dari sumberdaya manusia tidak sesuai dengan kelompok sasaran yang sama sekali tidak bisa berbahasa Indonesia. Sedangkan untuk fasilitas fisik pelaksanaan program dilihat cukup memadai, sebab terdapat ruangserbaguna desa sebagai tempat pelatihan, ketersediaan media praktek penanaman padi semi organic saat pelatihan yang disiapkan pihak Korea Selatan beserta makan siang peserta, dan beberapa bantuan seperti bank sampah di setiap dusun untuk pelaksanaan program pengelolaan sampah, pembangunan gedung serbaguna tersendiri, dan pemberian pupuk untuk tanaman obat keluarga kepada kelompok tani wanita. Sumberdaya pada program pengembangan desa Sumbermulyo dinilai masih belum efektif untuk mencapai tujuan program sebab hanya indikator fasilitas fisik yang dapat terpenuhi pada program.

\section{c. Disposisi}

Pengertian disposisi yang dimaksud pada variabel ini adalah pengambil keputusan harus memiliki visi dan misi yang sama atau pemikiran yang sama mengenai tujuan dari program yang akan dilaksanakan dengan pelaksanaan kebijakan. Apabila pengambil keputusan dan pelaksana kebijakan memiliki perbedaan pandangan terkait tujuan program maka situasi akan menjadi lebih. Disposisi disini lebih mengarah kesamaan persepsi mengenai program yang dilaksanakan mulai dari pemerintah pusat tergambar dari rencana pembangunan presiden Jokowi, 
kemudian rencana pembangunan dari pemerintah D.I Yogyakarta, rencana pembangunan Kabupaten Bantul, sampai kepada rencana pembangunan desa Sumbermulyo bersinergi satu sama lain dan memiliki tujuan yang sama. Program pengembangan desa sendiri merupakan perwujudan dari program kerja pemerintahan Jokowi yang disebut NAWACITA dimana pemusatan pembangunan daerah dari kawasan pinggiran dan desa (Mochdar \& Mohammad, 2017). Di tingkatan pemerintahan D.I Yogyakarta dan Kabupaten Bantul, program pengembangan desa melalui peningkatan produk pertanian menjadi arah kebijakan utamanya di tahun 2012-2017 (RPJMD DIY 2012-2017,2013). Pada tingkatan pemerintahan desa Sumbermulyo, program peningkatan pertanian desa ini melalui kerjasama dengan pihak ketiga juga tertuang pada Rencana Kerja Pembangunan Desa Nomor 16 Tahun 2017 pada poin keempat terkait peningkatan kemitraan untuk penguatan usaha milik desa.

Rangkaian rencana pembangunan dari pusat sampai ke daerah yang menitik beratkan pada pengembangan desa dan kemitraan dengan pihak ketiga menunjukkan bahwa disposisi dari tujuan program ini berjalan dengan baik hingga ke desa, sebab program NAWACITA Jokowi, RPJMD D.I Yogyakarta, dan RKPDes Sumbermulyo berkesesuaian satu dan lainnya. Oleh sebab itu, dilihat dari variabel ini program kerjasama sister-province ini mencapai tujuannya hingga ke sub pelaksanan terkecilnya.

\section{d. Struktur Birokrasi}

Aspek struktur birokrasi ini berkenaan dengan standar operasional prosedur (SOP) setiap program dan kordinasi antar birokrasi pada pelaksanaan program. Pada program pengembangan desa Sumbermulyo ini terlihat bahwa terdapat ketiadaan SOP pelaksanaan program dari pihak ketiga atau kerjasama dengan pihak asing, sehingga mengaburkan kordinasi program dengan pemerintah provinsi D.I Yogyakarta. Ketiadaan SOP pelaksanaan kerjasama sister-province di tingkat desa sampai ke provinsi menimbulkan terputusnya jalur kordinasi terkait program tersebut di pihak pemerintah provinsi. Sehingga, pemberhentian pelaksanaan program di Sumbermulyo masih belum diketahui pada tingkatan provinsi bahkan ketiadaan SOP peninjauan kemitraan pihak ketiga di tingkat desa dan provinsi membuat program-program kerjasama sister-province tidak diketahui keberlanjutannya sampai pada waktu yang disepakati.

\section{Tingkatan Kerjasama Sister-City antara Pemerintah Yogyakarta dan Gyeongsangbuk-Do pada pengembangan desa Sumbermulyo}

Berdasarkan penjelasan diatas dapat dilihat bahwa kerjasama sister-city antara Pemerintah D.I Yogyakarta dan Gyeongsangbuk-Do dalam pengembangan desa Sumbermulyo hanya mencapai satu indikator implementasi kebijakan yaitu disposisi. Kerjasama ini adalah wujud dari kebijakan tertulis dari pemerintah pusat sampai ke desa. Namun, pelaksanaan di lapangan membuat kerjasama ini masuk dalam tingkatan yang dinamis dimana pada awalnya kerjasama ini berhasil melibatkan berbagai aktor penting mulai dari masyarakat sebagai targetnya, universitas sebagai media pembelajarannya melalui keikutsertaan Universitas Gadjah Mada dalam memberikan tambahan pengetahuan bagi masyarakat desa Sumbermulyo dalam mengelola padi organik, lembaga swadaya masyarakat yaitu Penabulu yang berperan menjembatani hubungan antara desa Sumbermulyo dengan Gyeongsangbuk-Do, serta dengan dinasdinas terkait seperti Dinas Pengendalian Penduduk Keluarga Berencana Pemberdayaan Masyarakat Dan Desa (DPPKBPMD-Bantul) yang menjadi representaif dari Kementerian Desa, Pembangunan Daerah Tertinggal dan Transmigrasi dalam lingkup daerah. Selain 
itu, program kerjasama ini juga telah membawa salah satu perwakilan petani desa Sumbermulyo untuk belajar tentang pertanian organik di Gyeongsangbuk-Do selama dua minggu di pertengahan tahun 2017. Keterlibatan berbagai aktor dalam menjalankan program-program pengembangan desa Sumbermulyo ini menunjukkan bahwa kerjasama ini pada awalnya memiliki antusiasme yang tinggi, namun hal tersebut hanya berjalan dalam kurun waktu dua tahun dari perjanjian kesepakatan kerjasama yang ditandatangani.

Pada akhir 2017, kerjasama yang terjalin antara kedua wilayah ini tidak memiliki keberlanjutan program. Meskipun, program kerjasama ini telah berhasil melaksanakan program berupa pertukaran pengetahuan pertanian organik kepada masyarakat dan pembangunan Gedung Serbaguna Sumbermulyo, kerjasama ini berada dalam situasi stagnan dan vakum di akhir tahun 2017 sampai tahun 2019. Hal ini dilatarbelakangi oleh kekurangan pendanaan dari pihak pemerintah Gyeongsangbuk-Do untuk melaksanakan program lanjutan di desa Sumbermulyo. Kondisi ini memperlihatkan bahwa kerjasama pemerintah D.I Yogyakarta dengan Gyeongsangbuk-Do pada pengembangan desa Sumbermulyo menempati tingkatan dinamis, sebab kerjasama ini pernah pada posisi tinggi, tetapi karena kurangnya antusiasme yang tinggi dari masyarakat desa Sumbermulyo untuk mengganti produk pertaniannya menjadi padi organik dan ketiadaan inovasi program untuk mengembangkan desa Sumbermulyo serta keterbatasan biaya dari pihak Gyeongsangbuk-Do menyebabkan kerjasama ini tidak berjalan.

\section{KESIMPULAN}

Berdasarkan pembahasan sebelumnya, bisa disimpulkan bahwa kerjasama sisterprovince antara D.I Yogyakarta dan Gyeongsangbuk-Do pada program pengembangan desa Sumbermulyo tidak berhasil. Hal ini dilihat dari empat variabel yang digunakan hanya satu variabel yang dapat dipenuhi yaitu variabel disposisi, sedangkan tiga variabel lainnya yaitu komunikasi, sumberdaya, dan struktur birokrasi tidak berjalan dengan baik. Meskipun, kerjasama tersebut di program pengembangan desa Sumbermulyo telah terlaksana selama dua tahun, kenyataannya tidak berhasil dilaksanakan sampai pada waktu yang telah disepekati. Kuantitas pelatihan yang diberikan yaitu empat kali dalam kurun waktu dua tahun tersebut juga tidak sesuai dengan kebutuhan untuk meningkatkan produk unggul bagi desa Sumbermulyo. Keterikatan kedua wilayah ini sebenarnya dikategorikan dalam tingkatan dinamis, sebab pada dua tahun awal program pengembangan desa Sumbermulyo telah berhasil melibatkan berbagai aktor mulai dari universitas, pemerintah, dan tokoh masyarakat, namun antusiasme dari kerjasama ini tidak berlangsung lama dan keterbatasan dana menjadikan kerjasama ini tidak dapat berkembang, sehingga kerjasama ini berada dalam tingkatan kerjasama sister-city yang dinamis.

Manfaat kerjasama sister-city seperti transfer knowledge, adanya peran aktif dan gagasan dari pemerintah daerah dan stakeholder terkait, mempererat persahabatan pemerintah dan masyarakat kedua belah pihak, dan pertukaran budaya kedua belah pihak tidak didapatkan secara maksimal pada kerjasama sister-province D.I Yogyakarta dengan Gyeongsangbuk-Do di program pengembangan desa Sumbermulyo. Hal ini sesuai dengan yang disebutkan Salam (dalam Nuralam, 2018) bahwa pemerintah Indonesia belum memiliki kesiapan pada penarapan konsep sister-city di berbagai wilayahnya, sebab orientasi dari konsepnya masih pada jumlah kerjasama yang ditandatangani bukan pada kualitas pelaksanaan kerjasama di wilayah tersebut.

Mengacu kepada konsep sister-city dan pendekatan implementasi kebijakan yang digunakan untuk mengkaji lebih lanjut kerjasama antara D.I Yogyakarta dengan 
Gyeongsangbuk-Do pada pengembangan desa Sumbermulyo terdapat beberapa saran untuk memaksimalkan kerjasama sister-province selanjutnya yaitu: pertama, program kerjasama yang ingin dilaksanakan sebaiknya dilakukan secara bottom-up tidak hanya dari pihak atas sehingga sesuai dengan kebutuhan dan karakteristik kelompok sasaran, kedua, sebaiknya pemerintah D.I Yogyakarta ataupun pemerintah desa membuat sebuah aturan ataupun setidaknya SOP dari pembuatan perjanjian kerjasama dan pelaksanaan kerjasama yang melibatkan pihak internasional sehingga kordinasinya bisa sampai kepada alur kordinasi pemerintahan tertinggi, ketiga, pemerintah D.I Yogyakarta setidaknya meninjau kembali pelaksanaan setiap kerjasama yang disepakati bukan hanya berfokus pada jumlah kerjasamanya.

\section{UCAPAN TERIMA KASIH}

Penulis mengucapkan terimakasih kepada Lembaga Penelitian Universitas AMIKOM Yogyakarta sebagai pemberi hibah penelitian kerjasama sister-province antara pemerintah D.I Yogyakarta dengan Gyeongsangbuk-Do pada periode 2018-2.

\section{DAFTAR RUJUKAN}

Bakry, U. S. (2015). Metode Penelitian Hubungan Internasional. Yogyakarta: Pustaka Pelajar. Humas Desa Sumbermulyo. (2019). Kunjungan Tokoh Agama dari Myanmar. Retrieved $\begin{array}{lll}\text { March } 14, & \text { 2019, from }\end{array}$ https://sumbermulyo.bantulkab.go.id/index.php/first/artikel/113

Humas Pemda DIY. (2019). Gubernur DIY Berharap Program Saemaul di DIY Berlanjut. Retrieved January 25, 2020, from https://jogjaprov.go.id/berita/detail/7837gubernur-provinsi-gyeongsangbuk-do-korea-selatan-berkunjung-ke-jogjakarta

Indraswari, F. V. (2015). Kerjasama Indonesia-Korea Selatan Dalam Pengembangan Desa Melalui Sistem Saemaul Undong (Studi Kasus Kerjasama Lintas Batas Daerah Istimewa Yogyakara-Gyeongsangbuk-Do). Jurnal Transformasi Global, 2(2), 42-61. Retrieved

from https://transformasiglobal.ub.ac.id/index.php/trans/article/view/28

Mochdar, S., \& Mohammad, N. (2017). Nawacita sebagai strategi khusus Jokowi periode okteber 2014-20 oktober 2015. Jurnal Kajian Politik Dan Masalah Pembangunan, 13(1), 1961-1975. Retrieved from https://media.neliti.com/media/publications/126198-ID-nawacita-sebagaistrategi-khusus-jokowi.pdf

Mukti, T. A. (2013). Paradiplomacy Kerjasama Luar Negeri oleh Pemda di Indonesia. (A. Sahide, Ed.). Yogyakarta: The Phinisi Press.

Nuralam, I. P. (2018). Peran Strategis Penerapan Konsep Sister City Dalam Menciptakan Surabaya Green-City. Journal of Applied Business Administration, 2(1), 144-151. https://doi.org/10.30871/jaba.v2i1.807

Nursanti. Heni (Kepala Divisi Kemakmuran Desa Sumbermulyo). Wawancara, 2019, 15 Agustsus.

Occeñola, P. (2017). Menjelajah waktu di Gyeongsangbuk-do, Korea. Retrieved from https://www.rappler.com/indonesia/gaya-hidup/173018-itinerary-

gyeongsangbuk-do-korea-selatan

Prayogo, M. F., \& Setiawati, N. A. (2017). Redistribusi Tanah Absentee di Desa Sumbermulyo, Kecamatan Bambanglipuro, Kabupaten Bantul Tahun 1974-1984. Universitas Gadjah Mada.

Primawanti, H., Dermawan, W., \& Ardiyanti, W. (2019). Kerjasama Pemerintah Provinsi DKI Jakarta Dengan Pemerintah Kota Beijing China Dalam Skema Sister City. JPI: Jurnal of 
Political Issues, 1(1), 10-22. https://doi.org/10.33019/jpi.v1i1.3

Sinaga, 0. (2010). Otonomi daerah \& kebijakan publik: implementasi kerja sama Internasional. (D. J. Iskandar, Ed.). Bandung: Lepsindo.

Sirajuddin, I. A. (2014). Implementasi Kebijakan Pemerintah Daerah Dalam Pelayanan Publik Dasar Bidang Sosial Di Kota Makassar. Jurnal Ilmiah Ilmu Administrasi Publik, 4(1), 114. https://doi.org/10.26858/JIAP.V4I1.1817

Sitinjak, E., Sagala, S., \& Rianawati, E. (2014). Opportunity forSister City Applicationto Support Resilience City (8 No. https://www.rdi.or.id/file/pdf/8.pdf). Bandung.

Windiani, R. (2014). Implementasi Sister Province Provinsi Jawa Tengah Dengan Negara Bagian Queensland Australia di Bidang Pertanian. Jurnal Ilmu Sosial, 13(2), 20-36. https://doi.org/10.14710/jis.13.2.2014.20-36 